\title{
The Influence of Heat Treatment on the Phononic Multilayer Sensor
}

\begin{abstract}
SEBASTIAN GARUS*
Institute of Mechanics and Fundamentals of Machinery Design, Faculty of Mechanical Engineering and Computer Science, Czestochowa University of Technology, 19 Armii Krajowej Str., 42-200 Czêstochowa, Poland

In the work, the transmission of aperiodic quasi one-dimensional sensor built of $\mathrm{Zr}_{55} \mathrm{Cu}_{30} \mathrm{Ni}_{5} \mathrm{Al}_{10}$ amorphous alloy was tested using the Transfer Matrix Method algorithm. Transmission peak shifts were analyzed depending on the temperature of the flowing liquid. The influence of annealing in the temperatures $693 \mathrm{~K}$ and 773K of the amorphous alloy on the structure of the sensor transmission bands was analyzed. The existence of bands in the examined structures has been shown. The best phononic properties were found in the structure heated to $773 \mathrm{~K}$.
\end{abstract}

Keywords: phononic, transfer marix, aperiodic, multilayers, acoustic

Despite various physical grounds, the phenomena occurring during the propagation of electromagnetic and mechanical waves are similar to each other. For both types of waves, similar phenomena occur, such as the lack of propagation of waves of given frequencies in the analyzed structures (occurrence of a band gap). The properties of electromagnetic waves are examined for photonic structures [1-6], while mechanical waves are analyzed in phononic structures [7-15]. Depending on the application, one, two and three-dimensional phononic crystals are used and their properties depend on the geometrical structure and type of materials used in the composite [16]. Designed phononic crystals can be used to control the flow in fire acoustic devices [17] or as selective filters [18, 19].

Many of the studies focus on determining the band structure [20-23], but unfortunately it is not possible to determine it for distributions that do not have spatial periodicity. Numerically real structures can be simulated using the FDTD algorithm [9, 24, 25]. Quasi onedimensional cases can be solved analytically using Transfer Matrix Method algorithm [9].

\section{Transfer Matrix Method algorithm}

The mechanical wave falls on the structure $P_{i n}^{(+)}$, propagates inside it, after which part of the wave is transmitted $P_{\text {out }}^{(+)}$and the rest is reflected $P_{\text {in }}^{(-)} \cdot P_{\text {out }}^{(+)}$. is always zero. The $d$ is the layer thickness.

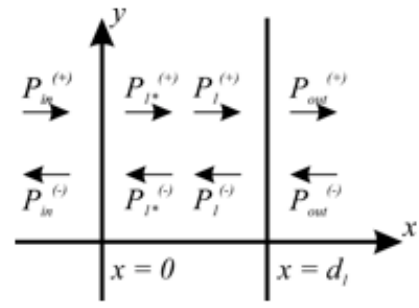

Fig. 1. Mechanical wave propagation in one layer structure.

The case of wave transmission in a single layer presented in Fig. 1 describes a system of equations

$$
\left\{\begin{array}{c}
{\left[\begin{array}{l}
P_{\text {in }}^{+} \\
P_{\text {in }}^{-}
\end{array}\right]=\Phi_{\text {in } 1}\left[\begin{array}{l}
P_{1^{+}} \\
P_{1^{-}}^{-}
\end{array}\right]} \\
{\left[\begin{array}{l}
P_{1^{+}}^{+} \\
P_{1^{-}}^{-}
\end{array}\right]=\Gamma_{1}\left[\begin{array}{l}
P_{1}^{+} \\
P_{1}^{-}
\end{array}\right]} \\
{\left[\begin{array}{l}
P_{1}^{+} \\
P_{1}^{-}
\end{array}\right]=\Phi_{\text {1,out }}\left[\begin{array}{l}
P_{\text {out }}^{+} \\
P_{\text {out }}^{-}
\end{array}\right]}
\end{array}\right.
$$

Occurring in Eq. (1) transmission matrix between the layers is defined as

$$
\Phi_{i, i+1}=\frac{1}{2}\left[\begin{array}{ll}
\frac{Z_{i}+Z_{i+1}}{Z_{i}} & \frac{Z_{i+1}-Z_{i}}{Z_{i}} \\
\frac{Z_{i}-Z_{i+1}}{Z_{i}} & \frac{Z_{i}+Z_{i+1}}{Z_{i}}
\end{array}\right]
$$

where $Z$ is an acoustic impedance depending on the mass density $\rho$ of $i$ layer material and the mechanical waves propagation velocity $v$, determined by the dependence

$$
Z_{i}=v_{i} \rho_{i}
$$

The $Z_{i}$ layer propagation matrix $i$ is defined as

$$
\Gamma_{i}=\left[\begin{array}{cc}
e^{i k d_{i}} & 0 \\
0 & e^{-i k_{i} d_{i}}
\end{array}\right]
$$

where the wave vector $k$ for frequency $f$ is given by

$$
k_{i}=\frac{2 \pi f}{v_{i}}
$$

In the abbreviated form, Eq. (1) can be written as

$$
\left[\begin{array}{c}
P_{i n}^{+} \\
P_{\text {in }}^{-}
\end{array}\right]=\Phi_{\text {in }, 1} \Gamma_{1} \Phi_{1, \text { out }}\left[\begin{array}{l}
P_{\text {out }}^{+} \\
P_{\text {out }}^{-}
\end{array}\right]
$$

Assuming that

$$
M=\Phi_{\text {in } 1} \Gamma_{1} \Phi_{1, \text { out }}
$$

received

$$
\left[\begin{array}{c}
P_{\text {in }}^{+} \\
P_{\text {in }}^{-}
\end{array}\right]=M\left[\begin{array}{l}
P_{\text {out }}^{+} \\
P_{\text {out }}^{-}
\end{array}\right]
$$

$M$ is called the characteristic matrix of the system and depends on the structure distribution and material properties of the composites components.

For $n$ the number of layers, the characteristic matrix takes the form

$$
\begin{aligned}
& \mathrm{M}=\Phi_{i n, 1} \Gamma_{1} \Phi_{1,2} \Gamma_{2} \Phi_{2,3} \Gamma_{3} \Phi_{3,4} \Gamma_{4} \Phi_{4,3} \ldots \\
& \quad \cdots \Phi_{n-2, n-1} \Gamma_{n-1} \Phi_{n-1, n} \Gamma_{n} \Phi_{n, \delta<}
\end{aligned}
$$

What can be written as 


$$
\mathrm{M}=\Phi_{i n, 1}\left[\prod_{i=2}^{n} \Phi_{i-1, i} \Gamma_{i}\right] \Phi_{n, \text { out }}
$$

The transmission coefficient $T$ can be determined from the characteristic matrix $M$

$$
T=\left|\frac{1}{\mathrm{M}_{1,1}}\right|
$$

\section{Analyzed structures and materials}

The $\mathrm{A}_{20} \mathrm{SA}_{20}$ multilayer structure was analyzed in the work. The $S{ }^{20}$ SS Severin structure [26], which for $L=4$ is BBABBBABABABBBAB. The $A$ is distilled water and $A_{20}$ means that it has a temperature of 20 degrees Celsius [ $27^{\circ}$, 28]. Material $B$ is $\mathrm{Zr}_{55} \mathrm{Cu}_{30} \mathrm{Ni}_{5} \mathrm{Al}_{10}$ amorphous alloy [29].

The speed of propagation of mechanical waves in distilled water (material A) depending on the temperature $[27,28]$ in the range from 10 to 55 degrees Celsius is described by the Eq. (12) and shown in Figure 2.

$$
\begin{gathered}
v(T)=1,40238744 \cdot 10^{3}+5,03836171 T- \\
-5,81172916 \cdot 10^{-2} T^{2}+3,34638117 \cdot 10^{-4} T^{3}- \\
-1,48259672 \cdot 10^{-6} T^{4}+3,16585020 \cdot 10^{-9} T^{5}
\end{gathered}
$$

The study investigated the influence of annealing of the $\mathrm{Zr}_{55} \mathrm{Cu}_{30} \mathrm{Ni}_{5} \mathrm{Al}_{10}$ amorphous alloy on the designed sensor transmission bands. The material parameters used are summarized in Table 1.

\section{Results and discussions}

In the work, was analyzed the transmission of a mechanical wave through a multilayer structure built of an amorphous alloy, between which distilled water flows with temperatures ranging from 10 to 55 degrees Celsius. The entire structure was immersed in distilled water at 20 degrees Celsius. Thicknesses of the layers have been selected so that the constructive interference inside the structure takes place. The tests were carried out for the amorphous alloy after solidification (Fig. 3a and 4a) and for samples heated for 10 min at 693K (Fig. 3b and 4b) and 773K (Fig. $3 \mathrm{C}$ and $4 \mathrm{C}$ ). The tests were carried out for a water temperature of 20 degrees Celsius in the frequency range from 0 to $2 \mathrm{MHz}$ (Fig. 3).

For the as quench and annealed in $693 \mathrm{~K}$ structures, the existence of two wide bandgap was found, while in the annealed sample at $773 \mathrm{~K}$ there were three bandgaps (Fig. 3). Then, for the frequency range from $850 \mathrm{kHz}$ to 1150

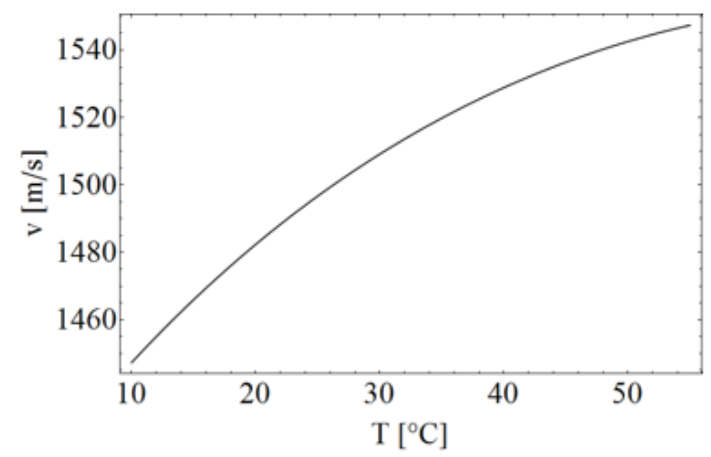

Fig. 2. Influence of temperature on the speed of propagation of mechanical waves in distilled water $[27,28]$

Amorphous alloys due to their unique magnetic properties can be used as transformer cores [30-37]. However, the structure demonstrating the lack of longrange ordering exhibits interesting properties as a component for composite phononic structures [29].
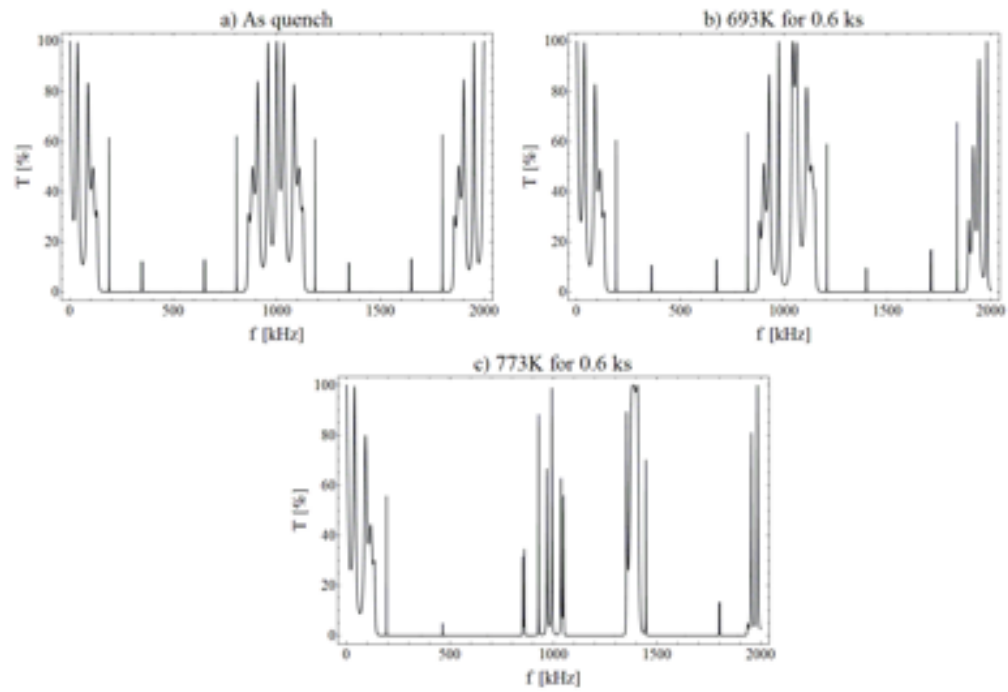

Fig. 3. Transmission of the analyzed structure for the amorphous alloy a) as quench and after $600 \mathrm{~s}$ in b) $693 \mathrm{~K}$ and c) 773K.

\begin{tabular}{|c|c|c|c|c|}
\hline Material & Type & $\begin{array}{c}\text { Mass density } \\
\mathbf{\rho}\left[\mathbf{k g} / \mathbf{m}^{3}\right]\end{array}$ & $\begin{array}{c}\text { Velocity of sound } \\
\mathbf{v}[\mathrm{m} / \mathrm{s}]\end{array}$ & $\begin{array}{c}\text { Layer thickness d } \\
{[\mu \mathrm{m}]}\end{array}$ \\
\hline $\mathrm{Zr}_{55} \mathrm{Cu}_{30} \mathrm{Ni}_{5} \mathrm{Al}_{10}$ & As quench & & 1633 & \\
\hline Distilled water & $693 \mathrm{~K}$ for $0.6 \mathrm{ks}$ & 6829 & 1702 & 816,5 \\
\hline & $773 \mathrm{~K}$ for $0.6 \mathrm{ks}$ & & 2257 & \\
\hline
\end{tabular}

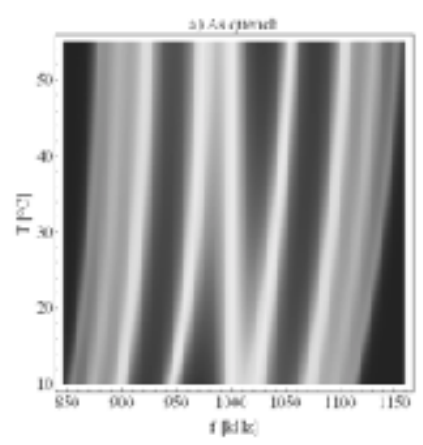

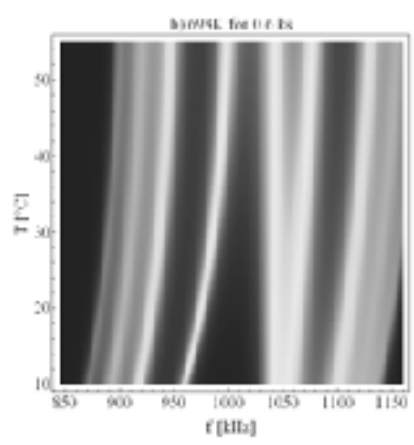

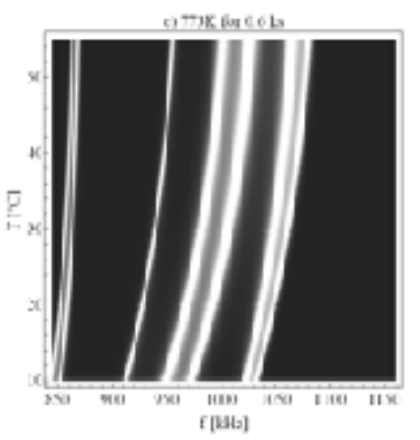

Table 1

MATERIAL PROPERTIES USED IN CALCULATIONS [27-29]

Fig. 4. Influence of distilled water temperature on transmission 
$\mathrm{kHz}$, the analysis of the influence of the water temperature inside the structure on the shifts of the transmission peaks was performed (Fig. 4). A small change in the mechanical wave propagation velocity between the base amorphous sample and annealed at $693 \mathrm{~K}$ caused non-linear shifts of temperature-dependent transmission peaks (Fig. $4 a$ and 4b). The high value and small half-widths of the peaks for the sample after annealing at 773K in the most visible way reflect the relationship between the water temperature and the shifts of the transmission peaks.

After measuring the sensor, the shift of the transmission peaks allows to determine the fluid temperature.

\section{Conclusions}

The study investigated the effect of annealing a sensor constructed of a quasi one-dimensional aperiodic structure built of an amorphous alloy. The best properties for the detector with a frequency of about $1 \mathrm{MHz}$ showed a structure soaked at $773 \mathrm{~K} \mathrm{in} 10 \mathrm{~min}$. There were three bandgaps and high-speed peaks with a small half-width. The high sensitivity of ultrasonic sensors based on aperiodic structures allows, apart from determining the temperature, to show small admixtures to the base material.

\section{References}

1.BOUFENAR, R., BOUAMAR, M., HOCINI, A., Chinese Journal of Physics, 56, no. 3, June 2018, p. 1126.

2.ZHANG, L., LIU, B., WANG, J., TAO, S., YAN, Q., J ournal of Colloid and Interface Science, 509, 2018, p. 318.

3.SZOTA, M., NABIALEK, M., GARUS, S., GARUS, J., BLOCH, K., Archives of Materials Science and Engineering 64, 2, 2013, p. 213.

4.GARUS, S., GARUS, J., SZLAZAK, K., NABIALEK, M., PIETRUSIEWICZ, P., BLOCH, K., GRUSZKA, K., SZOTA, M., J ournal of Achievements in Materials and Manufacturing Engineering, 61, no. 2, 2013, p. 236. 5.GARUS, S., GARUS, J., NABIALEK, M., GRUSZKA, K., BLOCH, K., Archives of Materials Science and Engineering, 64, no. 2, 2013, p. 110. 6.SZOTA, M., Rev. Chim (Bucharest), 69, no. 1, 2018, p. 166.

7.LU, Y., SRIVASTAVA, A., Journal of the Mechanics and Physics of Solids, 111, 2018, p. 100.

8.GARUS, S., SZOTA, M., Rev. Chim (Bucharest), 69, no. 3, 2018, p. 735.

9.GARUS, S., SOCHACKI, W., J ournal of Applied Mathematics and Computational Mechanics, 16, no. 4, 2017, p. 17.

10.GARUS, S., SOCHACKI, W., BOLD, M., Engineering Mechanics 2018 (ed.) FISCHER Cyril, NAPRSTEK Jiri, Institute of Theoretical and Applied Mechanics of the Czech Academy of Sciences, Prague, 2018, p. 229

11.TUGUI, C.A., NEJ NERU, C., GALUSCA, D.G., PERJU, M.C., AXINTE, M., CIMPOESU, N., VIZUREANU, P., Journal Of Optoelectronics And Advanced Materials, 17, no. 11-12. 2015, p. 1855.

12.BALTATU, M.S., VIZUREANU, P., CIMPOESU, R., ABDULLAH, M.M.A., SANDU, A.V., Rev. Chim (Bucharest), 67, no. 10, 2016, p. 2100.
13.ACHITEI, D.C., VIZUREANU, P., MINCIUNA, M.G., SANDU, A.V., BUZAIANU, A., DANA, D.I., Mat. Plast., 52, no. 2, 2015, p. 165.

14.VIZUREANU, P.,SAMOILA, C., COTFAS, D., Environmental Engineering And Management Journal. 8, no. 2, 2009, p. 301.

15.SANDU, A.V., CODDET, C.,BEJ INARIU, C., J ournal Of Optoelectronics And Advanced Materials, 14, no. 7-8, 2012, p. 699.

16.LU, M. H., FENG, L., CHEN, Y. F., Mater. Today, 12 no. 12, 2009, p. 34.

17.NIEGODAJEW, P., fUKASIAK, K., RADOMIAK, H., MUSIAL, D., ZAJEMSKA, M., POSKART, A., GRUSZKA, K., Combustion and Flame, 194, 2018, p. 245.

18.KRIEGEL, I., SCOTOGNELLA, F., Physica E, 85, no. 34, 2017, p. 34. 19.VILLA-ARANGO, S., TORRES, R., KYRIACOU, P.A., LUCKLUM, R., Measurement, 102, no. 20, 2017, p. 262.

20.LI, Y.F., MENG, F., LI, S., JIA, B., ZHOU, S., HUANG, X., Physics Letters A, 382, no. 10, 2018, p. 679.

21.LIU, Y., SU, J.Y., XU, Y.L., ZHANG, X.C., Ultrasonics, 49, 2009, p. 276.

22.VASSEUR, J.O., DJAFARI-ROUHANI, B., DOBRZYNSKI, L., DEYMIER, P.A., J. Phys.: Condens. Matter, 9, 1997, p. 7327.

23.ZHONG, L., WU, F., ZHANG, X., ZHONG, H., ZHONG, S., Phys. Lett. A, 339, 2005, p. 164.

24.SULLIVAN, D.M., Electromagnetic Simulation Using the FDTD Method, IEEE Press, New York 2000.

25.TAFLOVE, A., Computational Electrodynamics: The FiniteDifference Time-Domain Method, Artech House Inc., Norwood, MA, 1995

26.SEVERIN, M., DULEA, M., RIKLUND, R., J. Phys.: Condens. Matter, 1, no. 45,1989 , p. 8851.

27.BILANIUK, N., WONG, G.S.K., J Acoust Soc Am, 93, 1993, p. 1609. 28.BILANIUK, N., WONG, G.S.K., J Acoust Soc Am, 99, 1996, p. 3257 29.FUKUHARA, M., WANG, X., INOUE, A., J Non-Cryst Solids, 356, 2010, p. 1707.

30.NABIALEK, M.G., PIETRUSIEWICZ, P., DOSPIAL, M.J., SZOTA, M., B£OCH, K., GRUSZKA, K., O •GA, K., GARUS, S., J ournal of Alloys and Compounds, 615, 2014, p. S51

31.GARUS, S., NABIALEK, M., BLOCH, K., GARUS, J., Acta Phys. Pol. A, 126, no. 4, 2014, p. 957.

32.GONDRO, J., BLOCH, K., NABIALEK, M., GARUS, S., Materials and Technologies, 50, no. 4, 2016, p. 559.

33.GARUS, J., GARUS, S., NABIALEK, M., SZOTA, M, Acta Phys. Pol. A, 126, no. 4, 2014, p. 954.

34.GRUSZKA, K., NABIALEK, M., SZOTA, M., BLOCH, K., GONDRO, J., PIETRUSIEWICZ, P., SANDU, A.V., MUSTAFA AL BAKRI, A. M., WALTERS, S., WALTERS, K., GARUS, S., DOSPIAL, M., MIZERA, J., Arch. Metall. Mater., 61, no. 2, 2016, p. 641.

35.BLOCH, K., NABIALEK, M., DOSPIAL, M., GARUS, S., Arch. Metall. Mater., 60, no. 1, 2015, p. 7.

36.GARUS, S., NABIALEK, M., GARUS, J., Acta Phys. Pol. A, 126, no. 4, 2014, p. 960.

37.BLOCH, K., NABIALEK, M., GARUS, S., Acta Phys. Pol. A, 130, no. 4, 2016, p. 905.

Manuscript received: 19.07 .2019 